\title{
The Relationship between Earnings-to-Price, Current Ratio, Profit Margin and Return: An Empirical Analysis on Istanbul Stock Exchange
}

\author{
Hakkı Öztürk $^{1} \&$ Tolun A. Karabulut ${ }^{2}$ \\ ${ }^{1}$ Department of International Finance, Faculty of Economics, Administrative and Social Sciences, Bahçeşehir \\ University, Istanbul, Turkey \\ ${ }^{2}$ Graduate School of Social Sciences, Bahçeşehir University, Istanbul, Turkey \\ Correspondence: Hakkı Öztürk, Department of International Finance, Bahçeşehir University, Istanbul, Turkey.
}

Received: November 2, 2017

Accepted: November 17, $2017 \quad$ Online Published: November 20, 2017

doi:10.5430/afr.v7n1p109

URL: https://doi.org/10.5430/afr.v7n1p109

\begin{abstract}
This paper aims to investigate the relationship between current ratio, earnings to price, net profit margin and stock returns in İstanbul Stock Exchange over the period 2008-2016 by employing panel data analysis. Due to the existence of heteroskedasticity, cross sectional dependence and autocorrelation in the sample data, robust estimators are used to estimate two-way fixed effects model is estimated. Both Parks-Kmenta and Beck-Katz methods are conducted to check whether the results are consistent or not. According to Park-Kmenta estimation model, the results show that earnings to price and net profit margin are significant to explain stock returns in İstanbul Stock Exchange while current ratio is found insignificant. Moreover, the test based on Beck-Katz model produces the similar results. Earnings to price and net profit margin are strong determinants of stock returns in Istanbul Stock Exchange. Stocks with higher E/P ratios and profit margins generate higher returns for the next period.
\end{abstract}

Keywords: Earnings to Price, Current Ratio, Profit Margin, Two Way Fixed Effects Model

JEL Classification: C23, G10

\section{Introduction}

Over the past long years, financial ratios have attracted equity investors and there has been a remarkable interest in financial ratios since they have been used to predict stock returns. There are a lot of macroeconomic and firm specific factors that affect stock returns which make equity valuation much more difficult and complex than other securities. Hence, analyzing the factors that drive stock returns is a major concern and very important to investors and portfolio managers in stock markets.

Although Fama $(1965,1970)$ stated empirical evidence of that date provided strong support for the random walk theory and in case of market efficiency and both technical and fundamental analysis were useless to gain extra returns in stock markets, the relation between financial ratios and stock returns has been extensively investigated in the financial literature. There are many studies which focus on the major determinants of stock returns. The existing literature contains macroeconomic and financial factors to capture the impacts on stock returns and many financial ratios have been used to analyze the empirical relationship with stock returns such as liquidity ratios, debt ratios, profitability ratios, etc.

The main objective of this study is to investigate the relationship between financial ratios and stock returns of Technology related to Istanbul Stock Exchange. Current ratio, earnings to price and net profit margin are chosen to analyze the relationship with stock returns. The paper is structured as follows: Section 2 presents literature review, in section 3 data and methodology is documented and Section 4 concludes.

\section{Literature Review}

Lewellen (2004), studied whether dividend yield, book to market and earnings to price ratios to predict stock returns in New York Stock exchange over the period 1946-2000. According to the results, there is a potent evidence that B/M and E/P forecast both equal- and value- weighted NYSE returns over the period 1963-1994. However, in $1995-2000$ period, B/M and E/P ratios were found to be significant on an equal-weighted index.

Chang, Chang, Chen and Su (2008), employed panel data to analyze the relationship between stock prices in Taiwan stock market and earnings-per-share under the different level of growth rate of operating revenue. As a primary 
conclusion, they pointed out there is a significant relationship between EPS and prices in the long run. Correspondingly, Srinivasan (2012) reported earnings per share and price-earnings ratios are significant determinants of stock prices of different sectors in Indian economy over the period 2006-2011. Similarly, Shen (2000) found high price earnings ratios have been followed by negative stock returns in the short and the long-run in S\&P Index.

Kheradyar, Ibrahim and Nor (2011), studied stock return predictability with financial ratios. The study is applied in the Malaysia stock exchange for the period between January 2000 and December 2009. In this study, dividend yield, earning yield and book-to-market ratio have been selected as predictor variable. As an estimation method, generalized least squares (GLS) technique is employed to analyze the predictive power of selected financial ratio on the return of stock. As a result of the study, book-to-market ratio has more predictive power than other financial ratios, selected for this study. Moreover, the combination of those three financial ratios increase the predictive power of regressors on stock return.

Karan (1996) performed the first study on the Istanbul Stock Exchange (ISE) to analyze the P/E effect over the period April 1989- March 1995. He constructed 30 portfolios which had high, low and medium P/E ratios. The results of the study showed that there is a P/E effect in ISE and it is possible to have higher returns in the long term, in case of investing in low P/E portfolios. Likewise, Horasan (2009) also examined the effect of price to earnings ratio of stock prices and stock returns in ISE between 2000 and 2006. The results in this study suggest that, while there is a significant and positive relationship between price and price to earnings ratio, there is a significant but negative relationship between price to earnings ratio and returns.

Nargelecekenler (2011), searched the relationship between price/earnings ratio and stock prices in Istanbul Stock Exchange for 24 sectors using panel data analysis over the period 2000-2008. According to the findings, there is not a significant P/E effect in all sectors. A significant relationship between stock price and PE ratio is found for just 6 of 24 sectors per six-month period and for 5 sectors per three-month period.

Another study related to effects of financial ratios on the market value of stocks, is conducted by Uluyol and Turk (2013). In the study, 56 manufacturing firms listed in the Istanbul Stock Exchange have been analyzed for a period between 2004 and 2010. The effects of regressors were predicted by using robust estimators in panel data model. According to findings of this study, current ratio and cash ratio have significant effects on the firm value.

Dadrasmoghaddam and Akbari (2015), studied the effects of financial ratios on stock prices of agriculture related companies, listed on the Stock Exchange of Iran. They have used ten years data (from 1999 to 2009) and have examined the effect of the current ratio, asset turnover, the profitability (return on assets and return of equity), debt ratio and equity prices by using panel data analysis. The results of this study have indicated that current ratio, debt ratio and return on assets have a statistically significant effect on stock price. On the other hand, Bagherzadeh, Safania and Roohi (2013) studied the relationship between current ratio and share price of the companies listed in National Stock Exchange of India from 2009 to 2012. According to the results, there isn't a statistically significant relationship between share price and current ratio.

Basu (1977) found that low P/E portfolios seem to have earned higher absolute and risk-adjusted rates of return than the portfolios with high P/E ratios on average for the period from April 1957 to March 1971 in New York stock exchange. A similar study conducted by Basu (1983) found that stock returns are related to company size and profits. During the period of 1963-1980, in New York stock exchange higher earnings price ratios gained higher returns on average compared to lower earnings price ratios.

Petcharabul and Rompasert (2014) studied technology sector in Thailand Stock Exchange from 1997 to 2011. Current ratio, debt-to-equity ratio, inventory turnover, return on equity and price earnings ratios were selected as dependent variables and ordinary least squares regression was applied to test the relationship for the study. As a result of regression analysis, it was indicated that only ROE and PE were related to stock returns.

Dita and Murtaqi (2014) studied the relationship between net profit margin, price to book value, debt-equity ratios and stock returns in the Indonesian consumer goods industry during the period 2009-2013. According to the results of multiple linear regression analysis, net profit margin, price to book value, and debt equity ratio have a significant relationship between stock returns. As a result of this study, net profit margin and debt to equity ratio have a positive effect, while the price to book value has a statistically significant negative relationship with stocks returns. They also stated that NPM is the most significant factor compared to PBV and DER.

Allozi and Obeidat (2016) examined the relationship between profitability and leverage measures with stock returns in Amman stock Exchange. The sample included 65 manufacturing companies over the period 2001-2011. They used net profit margin, gross profit margin, return on assets, return on equity and earnings per share as profitability and 
debt ratio, debt to equity ratio and interest coverage ratio as leverage ratios. The results showed that gross profit margin, return on equity, return on assets and earnings per share have significant relationship with stock returns and net profit margin and leverage measures are irrelevant with stock returns.

Kalayci and Karatas (2005) explored the relationship between financial ratios, including current ratio and stock returns, traded in ISE. Sample sectors which were chosen for that research were chemical, paper \& paper products, petroleum, plastics and food \& beverages. As a result of that research, it seemed the liquidity ratios were only able to explain the stock returns for the paper and paper product sectors. Another study about the relationship between liquidity ratio and stock returns was applied by Gharaibeh (2014) on Amman stock exchange. That study showed that there is a weak but significant relationship between liquidity (current ratio) and stock returns.

\section{Data and Methodology}

The data set contains 14 companies, listed in Istanbul Stock Exchange (ISE) which are operating in technology and communication sector for the period between 2008 and 2016. We use quarterly data since financial statements in Borsa İstanbul are announced quarterly. 32 quarters and 14 stocks generate 448 number of observations in panel data analysis. Stata software is used to conduct the analysis process.

The source of the data is Bloomberg. To be included in the sample stocks must have a continuous listing on Borsa İstanbul, must not be suspended or delisted and be actively traded over the period 2008-2016. The stocks that fulfill these requirements in technology and communication sector are Alcatel, Arena, Armada, Arcelik, Aselsan, Datagate, Indes, Karel, Logo, Netas, Plastik Kart, Turkcell, Turk Telekom and, Vestel.

Three financial ratios, Earnings to Price (E/P), Current ratio and Profit Margin are selected as explanatory variables in the model.

The dependent variable is stock return which is calculated as "[( Price $_{t}-$ Price $\left._{t-1}\right) /$ Price $\left._{t-1}\right]$ " where $t$ is referring to the quarters. As for independent variables, current ratio, which measures short term debt-paying ability, is calculated current assets divided by current liabilities. Calculation of $\mathrm{E} / \mathrm{P}$ is earnings per share divided by stock price for a given period of time and net profit margin, measuring net income generated by each currency unit of sales, is calculated net income divided by net sales.

The panel data regression model is employed to examine time series of cross-section observations and to determine the relationship between dependent and independent variables in this study. The model used in this study is expressed in Equation 1.

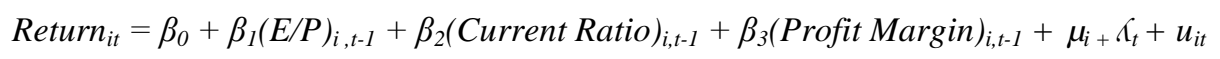

where $\mathrm{i}=1, \ldots, 14$ and $\mathrm{t}=1, \ldots, 32$ and $\mu_{\mathrm{i}}$ is referring to the unit variable and $\kappa_{\mathrm{t}}$ is referring to the time variable. $\beta_{0}$ is constant term and $\mathrm{u}_{\mathrm{it}}$ is an error term.

Table 1 shows the correlation matrix between variables. There is no significant correlation among any two independent variables so it can be stated that there is no multicollinearity in the model.

Table 1. Correlation Matrix

\begin{tabular}{lllll}
\hline & Return & E/P & Current Ratio & Profit Margin \\
\hline Return & 1.0000 & & & \\
E/P & 0.1751 & 1.0000 & & \\
Current Ratio & -0.0248 & -0.2062 & 1.0000 & \\
Profit Margin & 0.1098 & 0.1862 & -0.0255 & 1.0000 \\
\hline
\end{tabular}

Table 2 below presents unit root tests based on Augmented Dickey Fuller and Phillips-Peron which indicates whether variables in the series have a unit root or not. 
Table 2. Unit Root Test Results

\begin{tabular}{|c|c|c|c|c|c|c|c|c|}
\hline \multirow[t]{3}{*}{ Variables } & \multicolumn{8}{|l|}{ Methods } \\
\hline & \multicolumn{2}{|c|}{ ADF (intercept) } & \multicolumn{2}{|c|}{$\begin{array}{l}\mathrm{ADF}(\text { intercept, } \\
\text { trend) }\end{array}$} & \multicolumn{2}{|c|}{ PPeron (intercept) } & \multicolumn{2}{|c|}{$\begin{array}{l}\text { PPeron(intercept, } \\
\text { trend) }\end{array}$} \\
\hline & Statistic & Prob. & Statistic & Prob. & Statistic & Prob. & Statistic & Prob. \\
\hline Return & 230.585 & 0.0000 & 193.603 & 0.0000 & 251.299 & 0.0000 & 462.371 & 0.0000 \\
\hline $\mathrm{E} / \mathrm{P}$ & 54.1124 & 0.0022 & 40.1323 & 0.0644 & 57.7351 & 0.0008 & 303.426 & $0.0000 *$ \\
\hline $\begin{array}{l}\text { Current } \\
\text { Ratio }\end{array}$ & 52.0823 & 0.0038 & 81.3227 & 0.0000 & 54.9260 & 0.0017 & 95.7236 & 0.0000 \\
\hline $\begin{array}{l}\text { Profit } \\
\text { Margin }\end{array}$ & 185.017 & 0.0000 & 163.704 & 0.0000 & 214.988 & 0.0000 & 287.885 & 0.0000 \\
\hline
\end{tabular}

Note*Result is obtained by taking the first difference. All the other results are at levels.

According to Unit Root Test results, p values are lower than 0.05 , so the null hypothesis, which states variables contain a unit root, can be rejected. Series are stationary.

Panel data analysis is employed in order to examine the relationship between chosen variables and the stock returns. Before moving to panel data, F Test and Breusch-Pagan Langrange Multiplier tests are conducted to determine whether there are individual and time effects in the model. Table 3 shows F Test results and Table 4 presents Breusch-Pagan Langrange Multiplier test results. According to the test results in Table 3 and Table 4, there are both individual and time effects and two way panel data regression models should be used.

Table 3. F Test Results

\begin{tabular}{|c|c|c|c|c|}
\hline \multirow[t]{2}{*}{$\begin{array}{l}\text { F Test (for Fixed } \\
\text { Effects) }\end{array}$} & \multicolumn{2}{|c|}{$\begin{array}{l}\text { For Individual Effects }\left(\mathrm{H}_{0}: \text { All } \mu_{\mathrm{i}}=0 \text {; }\right. \\
\left.\mathrm{H}_{\mathrm{a}} \text { : Any } \mu_{\mathrm{i}} \neq 0\right)\end{array}$} & \multicolumn{2}{|c|}{$\begin{array}{l}\text { For Time Effects }\left(\mathrm{H}_{0}: \text { All } \Lambda_{\mathrm{t}}=0 ; \mathrm{H}_{\mathrm{a}} \text { : }\right. \\
\left.\text { Any } \Lambda_{\mathrm{t}} \neq 0\right)\end{array}$} \\
\hline & Statistic & Prob & Statistic & Prob \\
\hline Values & 2.10 & 0.0131 & 4.80 & 0.0000 \\
\hline Decision & Reject $\mathrm{H}_{0}$ & & Reject H & \\
\hline
\end{tabular}

Table 4. Breusch-Pagan Langrange Multiplier Test (For Random Effects)

\begin{tabular}{|c|c|c|c|c|}
\hline \multirow{2}{*}{$\begin{array}{l}\text { Breusch-Pagan } \\
\text { LM Test }\end{array}$} & \multicolumn{2}{|c|}{ For Individual Effects $\left(\mathrm{H}_{0}: \operatorname{Var}(\mu)=0\right)$} & \multicolumn{2}{|c|}{ For Time Effects $\left(\mathrm{H}_{0}: \operatorname{Var}(K)=0\right)$} \\
\hline & Statistic & Prob & Statistic & Prob \\
\hline Values & 2.63 & 0.1046 & 124.25 & 0.0000 \\
\hline Decision & Accept $\mathrm{H}_{0}$ & & Reject $\mathrm{H}_{0}$ & \\
\hline
\end{tabular}

Hausman test is applied to determine whether to use fixed or random effects model in panel data analysis. Hausman test result is exhibited in Table 5. Table 5 indicates that Two-Way Fixed Effects Model or Two-Way Mixed Effects Model can be used to determine whether there is a relationship between chosen financial ratios and returns.

Table 5. Hausman Test Results

\begin{tabular}{lll}
\hline Hypothesis & Hausman & Decision \\
\hline $\mathrm{H}_{0}: \mathrm{E}\left(\kappa_{\mathrm{t}} \mathrm{X}_{\mathrm{it}}\right)=\mathrm{E}\left(\mu_{\mathrm{i}} \mathrm{X}_{\mathrm{it}}\right)=0$ & 44.25 & Reject $\mathrm{H}_{0}$ \\
$\mathrm{H}_{0}: \mathrm{E}\left(\mu_{\mathrm{i}} \mathrm{X}_{\mathrm{it}}\right)=0$ & 13.04 & Reject $\mathrm{H}_{0}$ \\
$\mathrm{H}_{0}: \mathrm{E}\left(\kappa_{\mathrm{t}} \mathrm{X}_{\mathrm{it}}\right)=0$ & 2.10 & Do not Reject $\mathrm{H}_{0}$ \\
$\chi^{2}(4)=9.488$ & &
\end{tabular}

Two-way fixed effects model is selected as a panel data model. To test autocorrelation in the sample data, Wooldridge test has been employed. The null hypothesis of the test is " $\mathrm{H}_{0}$ : There is no first order autocorrelation.". According to test results, the null hypothesis is rejected, therefore we can state there is first order autocorrelation in the characteristic of selected data. 
Table 6. Wooldridge Test for Autocorrelation Results

\begin{tabular}{lcc}
\hline $\begin{array}{l}\text { Wooldridge Test for } \\
\text { Autocorrelation }\end{array}$ & Statistics & Probability \\
\hline & 8.031 & 0.0141
\end{tabular}

Cross-sectional dependence is tested by employing Breusch-Pagan LM Test of independence. The null hypothesis of this test is residuals across entities are not correlated. It is inferred from the test results in our model, the null hypothesis is rejected so there is a cross-sectional dependence in the model.

Table 7. Breusch-Pagan LM Test of Independence

\begin{tabular}{lcc}
\hline $\begin{array}{l}\text { Breusch-Pagan LM Test of } \\
\text { Independence }\end{array}$ & Statistic $\left(\chi^{2}(91)\right)$ & Probability \\
\hline & 196.963 & 0.0000
\end{tabular}

Table 8 shows Wald Test results in order to examine whether there is heteroscedasticity in the regression model or not. The null hypothesis of this test is, the variance is constant for each individual unit. The result of the Wald Test in Table 8 indicates that there is group-wise heteroscedasticity in the model.

Table 8. Modified Wald Test Result

\begin{tabular}{lll}
\hline Wald Test for Heteroskedasticity & Statistic $\left(\chi^{2}(14)\right)$ & Probability \\
\hline & 304.74 & 0.0000
\end{tabular}

Under the existence of autocorrelation, cross-sectional dependence and heteroskedasticity, the robust standard errors or estimators could be used to predict the results. Daniel Hoechle (2007) discussed the alternatives of using robust standard errors under different cases, including autocorrelation, cross-sectional dependence and heteroskedasticity. According to the study, Parks Kmenta or Beck \& Katz estimators could be used for the heteroscedastic, cross-sectionally dependent and AR(1) type of autocorrelation.

We employed both Parks-Kmenta and Beck- Katz methods to check whether the results are consistent or not. Parks-Kmenta method is based on feasible generalized least squares algorithm, and Beck- Katz method suggests to rely on ordinary least square coefficient with panel corrected standard errors. Table 9 shows the panel data results with Parks- Kmenta method.

Table 9. Parks-Kmenta Method

\begin{tabular}{lllll}
\hline Return & Coefficient & Std. Err. & Z statistics & Probability \\
\hline E/P & 0.9361113 & 0.1410627 & 6.64 & $0.000^{* *}$ \\
Current Ratio & 0.0033122 & 0.0087707 & 0.38 & 0.706 \\
Profit Margin & 0.00288 & 0.0009124 & 3.16 & $0.002^{* *}$ \\
Constant & 0.0550429 & 0.0622574 & 0.88 & 0.377 \\
Wald Chi ${ }^{2}$ (46) & 20397.89 & & & \\
indicate significance at 5\% & & &
\end{tabular}

According to the results shown in Table 9, E/P and profit margin are statistically significant where current ratio is not significant. Stock returns are related with E/P and profit margin over the period 2008-2016. Stocks with higher profit margins and $\mathrm{E} / \mathrm{P}$ ratios generate higher returns for the next period.

In order to check whether the results are consistent or not, panel data analysis with two-way fixed effect model is employed using Beck- Katz method. Table 10 shows the results of Beck-Katz method with Prais-Winsten estimator. 
Table 10. Beck-Katz Method (Prais-Winsten Estimator)

\begin{tabular}{lllll}
\hline Return & Coefficient & Std. Err. & Z statistics & Probability \\
\hline E/P & 0.9213945 & 0.2712053 & 3.40 & $0.001^{* *}$ \\
Current Ratio & 0.012554 & 0.0152836 & 0.82 & 0.41 \\
Profit Margin & 0.0031692 & 0.0016117 & 1.97 & $0.049^{* *}$ \\
Constant & 0.0514397 & 0.0681105 & 0.76 & 0.377 \\
$\mathrm{R}^{2}$ & 0.3409 & & & \\
Wald Chi $^{2}(16)$ & 20397.89 & & & \\
\hline ndicate significance at 5\% & &
\end{tabular}

The results, based on Beck-Katz method, also indicate that Earning to Price Ratio and Profit Margin have a statistically significant effect on returns. Current ratio is not related to stock returns over the sample period. In this sense, both Parks-Kmenta and Beck-Katz Method results support each other. They confirm that stocks with low P/E multiples have higher returns for the next period and stocks with higher profit margins generate higher returns for the next period.

\section{Conclusion}

In this study, E/P ratio, net profit margin and current ratio are examined whether they have significant effects on stock returns in the İstanbul Stock Exchange.

14 firms operating in technology and communication sector are selected for 32 quarters between December 2008 and September 2016.

Due to the existence of heteroskedasticity, cross sectional dependence and autocorrelation in the sample data, we use two-way fixed effects models with robust standard errors. Both Parks Kmenta and Beck-Katz methods are employed to check whether the results are consistent or not. According to these two methods, which confirm each other, Earning to Price Ratio and Profit Margin have positive significant relation with stock returns. We have not found any evidence of current ratio on stock returns in Istanbul Stock Exchange between the period 2008 and 2016. Results are consistent with previous literature (Lewellen, 2004; Srinivasan 2012; Shen 2000; Karan, 1996; Petcharabul \& Rompasert, 2014; Dita \& Murtaqi, 2014).

As a primary conclusion, stocks operating in technology and communication sector in the Istanbul Stock Exchange which have low P/E multiples, generate higher returns for the next period. Also, higher profit margins result in higher returns over the sample period.

\section{References}

Allozi, N. M \& Obeidat G. S.(2016). The Relationship between the Stock Return and Financial Indicators (Profitability, Leverage): An Empirical Study on Manufacturing Companies Listed in Amman Stock Exchange. Journal of Social Sciences, 5(3), 408 - 424. Retrieved from http://centreofexcellence.net/J/JSS/Vol5/No3/JSSarticle14,5_3_pp408-424.pdf

Bagherzadeh M. R., \&Safania S., \&Roohi M. (2013). Relationship between Current Ratio and Share Price - A study on NSE, INDIA (2009-2012). International Journal of Mathematical Sciences \& Applications, 3(1), 163-167.

Basu S. (1977). Investment Performance of Common Stocks in Relation to Their Price-Earnings Ratios: A Test of Efficient Market Hypothesis. Journal of Finance, 32(3), 663-682. https://doi.org/10.1111/j.1540-6261.1977.tb01979.x

Basu S. (1983). The Relationship between Earnings' Yield, Market Value and Return for NYSE Common Stocks. Journal of Financial Economics, 12, 129-156. https://doi.org/10.1016/0304-405X(83)90031-4

Chang, H.-L., Chen Y.-S., Su C.-W, \&Chang Y.-W. (2008). The Relationship between Stock Price and EPS: Evidence Based on Taiwan Panel Data. Economic Bulletin, 3(30), 1-12. Retrieved from https://econpapers.repec.org/article/eblecbull/eb-08c30034.htm

Dadrasmoghaddam A., \&Akbari S. M. (2015). Relationship between Financial Ratios in the Stock Prices of Agriculture-Related Companies Accepted on the Stock Exchange for Iran. Research Journal of Fisheries and Hydrobiology, 10(9),586-591. 
Dita A. H., \&Murtaqi I. (2014). The Effect of Next Profit Margin, Price to Book Value and Debt to Equity Ratio to stock Return in the Indonesian Consumer Goods Sector. Journal of Business and Management, 3(3), 305 - 315.

Fama, E. F. (1965). Random Walks in Stock Market Prices. Financial Analysts Journal, 21(5), 55-59. https://doi.org/10.2469/faj.v21.n5.55

Fama, E. F. (1970). Efficient Capital Markets: A Review of Theory and Empirical Work. The Journal of Finance, 25(2), 383-417. https://doi.org/10.2307/2325486

Gharaibeh, A. (2014). Capital Structure, Liquidity and Stock Returns, European Scientific Journal, $10(2), 171$ - 179.

Hoechle D. (2007). Robust Standard Errors for Panel Regressions with Cross- Sectional Dependence. Stata Journal, 7(3), 281-312. Retrieved from http://www.stata-journal.com/article.html?article=st0128

Horasan M. (2009), Effects of Price to Earnings Ratio on Stock Returns: A Practice on ISE 30 Index. Iktisadi ve Idari Bilimler Dergisi, 23(1), 181-192.

Kalayci S., \&Karatas A. (2005). Relationship between Common Stock Returns and Financial Ratios: A Research of Fundamental Analysis in ISE. Muhasebe ve Finansman Dergisi, 27, 146-157

Karan M. B. (1996). Hisse Senetlerine Yapılan Yatırımların Performanslarının Fiyat/Kazanç Oranına Göre Değerlendirilmesi:İMKB Üzerine Ampirik Bir Çalışma. İktisat, İşletme ve Finans, 119, 26-35

Kheradyar S., \&Ibrahim I., \&Nor M. F. (2011), Stock Return Predictability with Financial Ratios. International Journal of Trade, Economics of Finance, 2(5), 391-396. https://doi.org/10.7763/IJTEF.2011.V2.137

Lewellen J. (2004), Predicting Returns with Financial Ratios. Journal of Financial Economics, 74, $209-235$. https://doi.org/10.1016/j.jfineco.2002.11.002

Nargelecekenler, M. (2011). Stock Prices and Price/Earnings Ratio Relationship: A Sectoral Analysis with Panel Data. Business and Economics Research Journal, 2(2), 165-184. https://doi.org/10.25295/fsecon.322659

Petcharabul P., \&Romprasert S. (2014). Technology Industry on Financial Ratios and Stock Returns. Journal of Business and Economics, 5(5), 739-746. Retrieved from http://www.academicstar.us/issueshow.asp?daid=639

Shen, P. (2000). The P/E Ratio and Stock Market Performance. Federal Reserve Bank of Kansas City. Retrieved from https://www.kansascityfed.org/PUBLICAT/ECONREV/PDF/4q00shen.pdf

Srinivasan, P. (2012). Determinants of Equity Share Prices in India: A Panel Data Approach. The Romanian $\begin{array}{lllll}\text { Economic } \quad \text { Journal, } & \text { 205-228. } & \text { Retrieved from }\end{array}$ http://www.rejournal.eu/sites/rejournal.versatech.ro/files/issues/2012-12-01/553/srinivasan.pdf

Uluyol, O., \&Turk, V. E. (2013), Finansal Rasyolarun Firma Değerine Etkisi: Borsa İstanbul (BİST)’da Bir Uygulama. Afyon Kocatepe Universitesi İBF Dergisi, 4(2), 365-384. Retrieved from http://www.iibfdergi.aku.edu.tr/pdf/15_2/18.pdf 